\title{
Reclaiming the Neighbourhood. Urban redevelopment, citizen activism, and conflicts of recognition in Guangzhou
}

\section{Bettina Gransow}

\section{(2) OpenEdition Journals}

Electronic version

URL: http://journals.openedition.org/chinaperspectives/6425

DOI: $10.4000 /$ chinaperspectives. 6425

ISSN: 1996-4617

\section{Publisher}

Centre d'étude français sur la Chine contemporaine

\section{Printed version}

Date of publication: 1 June 2014

Number of pages: 17-27

ISSN: 2070-3449

\section{Electronic reference}

Bettina Gransow, «Reclaiming the Neighbourhood. Urban redevelopment, citizen activism, and conflicts of recognition in Guangzhou », China Perspectives [Online], 2014/2 | 2014, Online since 01 January 2017, connection on 28 October 2019. URL : http://journals.openedition.org/ chinaperspectives/6425; DOI : 10.4000/chinaperspectives.6425 


\title{
Reclaiming the Neighbourhood
}

\author{
Urban redevelopment, citizen activism, and conflicts of recognition in Guangzhou
}

\author{
BETTINA GRANSOW
}

\begin{abstract}
This study examines social interventions into the everyday life of residents, families, and communities during a redevelopment project in an old town neighbourhood of Guangzhou. It further analyses how citizen activism unfolds in response to these redevelopment interventions. To better understand contention over the renewal of an old town neighbourhood - beyond negotiation of compensation for economic losses - the study is structured by a recognition-theoretical model of social conflict following Axel Honneth and Nancy Fraser.
\end{abstract}

KEYWORDS: urban redevelopment, citizen activism, conflicts of recognition, Xiguan/Canton culture, demolition, resettlement (chaiqian anzhi).

\section{Introduction}

$\mathrm{R}$ edevelopment projects in densely populated Chinese cities are not only restructuring urban space in physical terms but are also intervening in the everyday lives of local residents, families, and communities. Such interventions may lead to involuntary resettlement, loss of income, and rupture of informal economies, social networks, and community ties. Along with problems associated with relocation and compensation, residents have to deal with grief over the loss of homes and places imbued with a sense of belonging, as well as concerns about the future and feelings of uncertainty, powerlessness, and anger about the lack of information and inability to participate in the process of redevelopment planning and implementation. Particularly in neighbourhoods with historical flair and culturally significant architecture, individual and collective memories are closely interwoven with the history of the place.

This paper uses a micro-study of old town redevelopment in the southern Chinese city of Guangzhou to illuminate the complex social dynamics of urban reconstruction in detail, especially as processes of deconstructing and reconstructing physical and imaginative spaces. It focuses on how residents are affected by the project intervention, and what leeway they have to make their ideas and demands heard. Are they concerned with material compensation alone, or also with recognition of their own experiences, collective memories, and views of life in their neighbourhood as well as with participating in reshaping the now contested urban space?

In the tradition of analyses of social conflict that view contention not as dysfunctional but rather as an expression of social change (Georg Simmel, Ralf Dahrendorf, and Lewis Coser), the focus here is on conflicts of recognition that arise within the process and that also continue to feed it. Primary attention is paid to the perspectives of the residents, especially those who continue attempting to voice their side of the conflict, to discern and achieve their rights, and to shape the renewal process to fit their own ideas of the place.

Based on my own participatory observation (2010-12), interviews with residents, exhibitions, and media documentation, (1) this study examines the social impact of a redevelopment project in Guangzhou's old town, a neigh- bourhood of cultural and historical interest. It also analyses how citizen activism has developed in response. To better understand the dispute beyond a simple matter of bargaining over economic compensation, it is structured on a recognition-theoretical model of social conflict that builds on Axel Honneth's debate with Nancy Fraser over redistribution and recognition. (2) I argue that social conflicts between residents and local governments arising from urban redevelopment extend beyond the question of redistributing material benefits and losses to trigger conflicts of recognition shaped by coercion, bargaining, and asymmetrical participation in the authoritarian yet highly commercialised process of transformation in China. While this case study cannot claim to be representative, it can contribute to understanding the complexity and dynamics of social conflicts, social segregation, and citizen activism arising from a social intervention in an inner-city neighbourhood.

\section{Protest research and the question of recognition}

The pilot project for redeveloping an old town neighbourhood in Guangzhou - which forms the basis for this study - extended over a period of several years and was marked by protests and collective actions by residents. Relevant points of study come from China-related protest research starting in the 1990s under the paradigm of "rightful resistance." (3) This paradigm shaped the early debate on rural protests, which subsequently also addressed urban protests on issues such as the environment and

1. I visited the site ten times and participated in three group interviews with residents of several hours each. I also participated in workshops, lectures, and an exhibition opening (December 2011) focussing on the impact of the old town project. Unless otherwise indicated, all the information is from oral or written Chinese sources. I thank Huang Yuan for helping with the social assessment teaching project and the residents for their kindness and patience in explaining their views of the project and its impact.

2. Nancy Fraser and Axel Honneth, Redistribution or Recognition? A Political-Philosophical Exchange, London, Verso, 2003.

3. Kevin J. O'Brien, "Rightful Resistance," World Politics, Vol. 49, No. 1, pp. 31-55; Kevin J. O'Brien and Li Lianjiang, Rightful Resistance in Rural China, Cambridge, Cambridge University Press, 2006; Critique by Elizabeth Perry, "Chinese Conception of 'Rights': From Mencius to Mao - and Now," Perspectives on Politics, Vol. 6, No. 1, 2008, pp. 37-50. 
labour. (4) Its focus has become more varied, including whether the protests seek to implement already existing rights or extend to gaining the ability to help formulate new legislation. ${ }^{(5)}$ In both rural and urban conflicts, expropriation (of land) and demolition of housing constitute primary motives for resistance. Major means of protest include individual and written petitions as well as attempts to mobilise delegates of the National People's Congress and the Chinese People's Political Consultative Conference. ${ }^{(6)}$ In addition to the forms and extent of protest, scholarly debate shows a special interest in whether they could endanger one-party rule in China and ultimately lead to regime change. (7) Some authors consider protest itself a form of participation. ${ }^{(8)}$ After Sidney Tarrow pointed to a lack of research on the relations between protest and policy response, this issue has attracted greater attention. ${ }^{\left({ }^{9}\right)}$ With research on protest movements linked to the paradigm of "resilient authoritarianism" from Andrew Nathan (2003), (10) terms such as "contentious authoritarianism" or "consultative authoritarianism" are employed to explore the many valences of protest and participation within the realm of authoritarianism. (11) "Bargaining authoritarianism" is used by Ching Kwan Lee and Yonghong Zhang to cover three practices of domination and subordination between grass-roots officials and protesting citizens, which they identify as micro-foundations of authoritarian domination, namely protest bargaining, bureaucratic absorption, and patron-clientelism. Lee and Zhang argue that all three of these tactics seek to depoliticise and commodify conflict. ${ }^{(12)}$ As illuminating and convincing as this analysis is, it nevertheless leaves open the extent to which the practice consists of tactical calculation by officials seeking to defuse any explosive political content, or whether these officials assume the protests are in fact economically motivated and can therefore also be solved by economic means.

In the case study presented here, what gradually crystallised from my participatory observation was that the main trigger for the conflicts was the matter of recognition or the lack thereof, in the form of regard or disregard for residents' problems, desires, demands, knowledge, and living conditions on the part of local planning and government offices. Conflicts of recognition are understood here in a broader context of social justice, redistribution, and participation. Residents' demands for recognition are differentiated in terms of their economic, social, cultural, and political dimensions. Recognition is viewed as a normative category making individual autonomy dependent on intersubjective agreement. ${ }^{(13)}$ Building on Axel Honneth, I define conflicts of recognition as social conflicts that arise from the individual or collective experience of disregard, and the resistance arising from this experience as opening a form of expression that serves to affirm one's own moral or social value. ${ }^{(14)}$ At the same time, this self-affirmation generates recognition within the group of protesters, which in turn can be reinforced by interaction with other social agents who support them. ${ }^{(15)}$ Whereas Fraser and Honneth refer explicitly to Western societies in their debate on redistribution or recognition, I place this definition of conflicts of recognition in the context of contemporary China marked by authoritarianism, market relations, and societal transformation, and distinguish three patterns of recognition, namely: 1) paternalist care/coercion and subordination where the state with its concentration of resources is capable of sustaining and stabilising authoritarian power in a reciprocal manner; 2) market-like exchange and distributive justice where market mechanisms are increasingly influencing all spheres of Chinese society, including state-society and statemarket relations, and where ever more citizens know and are defending their rights; 3) social differentiation/pluralisation and participation where rapid social transformation is producing new social groups that need to find ways of participating in decision-making processes regarding state, market, and societal issues. These three patterns of recognition stand for different relationships of solidarity and figurations of identity. They form the authoritarian/flexible framework in which conflicts of recognition are worked out in Chinese society. ${ }^{(16)}$ If subjects or groups feel that an agreed-upon pattern of recognition is failing or violated, this feeling may underlie the experience of "disrespect" and become the motivational basis for social conflicts. ${ }^{(17)}$

Before examining these nexuses more closely, I will describe the location in Guangzhou, its historical and cultural background, and sketch the rede-

4. Yu Jianrong, "Conflicts in the Countryside," China Perspectives, No. 2007/3, pp. 28-34; Cai Yongshun, Collective Resistance in China. Why Popular Protests Succeed or Fail, Stanford, Stanford University Press, 2010; Zhu jiangang and Wang Chao, "Jiti xingdong de celüe yu wenhua kuangjia de jiangou" (Tactics of collective action and the construction of a cultural framework), in Zhu jiangang (ed), Gonggong Shenghuo Pinglun. Shequ, Kongjian yu Xingdong (Public Life Review: Community, Space, and Action), No. 1, Beijing, Zhongguo shehui kexue chubanshe, 2010, pp. 31-70; You-tien Hsing and Ching Kwan Lee (eds), Reclaiming Chinese Society: The New Social Activism, London, Routledge, 2010.

5. Jiang Yihong, "Altering the Rules: Chinese Homeowners' Participation in Policy Making," Journal of Current Chinese Affairs, No. 3, 2013, pp. 121-148.

6. Chen Xi, Social Protests and Contentious Authoritarianism in China, Cambridge, Cambridge University Press, 2012; Carl F. Minzner, "Xinfang: An Alternative to Formal Chinese Legal Institutions," Stanford Journal of International Law, Vol. 42, No. 1, 2006, pp. 103-179; Bettina Gransow, "Das Petitionswesen in China - ein Instrument sozialer Gerechtigkeit?" (Petitioning in China - An Instrument of Social Justice?) in Der Bürger im Staat. Die Volksrepublik China (The Citizen in the State:The People's Republic of China), No. 3/4, Landeszentrale für politische Bildung Baden Württemberg, 2008, pp. 236-242.

7. Günter Schucher highlights the tendency in recent protest research on authoritarian regimes to view all kinds of protest as being directed against the regime, in Schucher, "Liberalisierung in Zeiten der Instabilität: Spielräume unkonventioneller Partizipation im autoritären Regime der VR China" (Liberalisation in Times of Instability: Margins of Unconventional Participation in Chinese Authoritarianism), German Institute of Global and Area Studies (GIGA) Working Papers, No. 103, June 2009.

8. Yu Jianrong, "Social Conflict in Rural China Today: Observations and Analysis on Farmers' Struggles to Safeguard Their Rights," Social Sciences in China, No. 3, 2005, pp. 125 ff.; Christian Cöbel and Lynette Ong, Social Unrest in China, Europe China Research and Advice Network 2012, p. 23, www.euecran.eu/ (accessed on 2 November 2013).

9. Sidney Tarrow, "Prologue:The New Contentious Politics in China: Poor and Blank or Rich and Complex?", in Kevin J. O'Brien (ed), Popular Protest in China, Cambridge Mass., Harvard University Press, 2008, p. 7; Cai Yongshun, "Local Governments and the Suppression of Popular Resistance in China," China Quarterly, No. 193 (March), 2008, pp. 24-42; Ching Kwan Lee and Yonghong Zhang, "The Power of Instability: Unraveling the Microfoundations of Bargained Authoritarianism in China," American Journal of Sociology, Vol. 118, No. 6, 2013, pp. 1475-1508.

10. Andrew Nathan, "Authoritarian Resilience" Journal of Democracy, Vol. 14, No. 1, 2003, pp. 6-17.

11. Chen Xi, Social Protests and Contentious Authoritarianism in China, op. cit:; He Baogang and Stig Thogerson, "Giving the People a Voice? Experiments with Consultative Authoritarian Institutions in China," Journal of Contemporary China, Vol. 19, No. 66, 2010, pp. 675-692.

12. Ching Kwan Lee and Yonghong Zhang, "The Power of Instability," art. cit.

13. See Nancy Fraser and Axel Honneth, Redistribution or Recognition? A Political-Philosophical Exchange, op. cit., p. 1; Nancy Fraser, "Social Justice in the Age of Identity Politics: Redistribution, Recognition and Participation, in ibid. pp. 9-16. For the contested process of individualisation in China see Mette Halskov Hansen and Rune Svarverud (eds), iChina: The Rise of the Individual in Modern Chinese Society, Copenhagen, NIAS Press, 2010.

14. I do not, however, follow Axel Honneth's approach of comprehending recognition as an overarching moral category while treating distribution as a derivative. (Nancy Fraser and Axel Honneth, Redistribution or Recognition? A Political-Philosophical Exchange, op. cit., pp. 2, 3).

15. Cf. Axel Honneth, Kampf um Anerkennung. Zur moralischen Grammatik sozialer Konflikte (Fighting for Recognition: A Moral Grammar of Social Conflicts), Frankfurt am Main, Suhrkamp, 1994, pp. 260, 263

16. The structure of the book by You-tien Hsing and Ching Kwan Lee, Reclaiming Chinese Society, op. cit., see p. 4, seems to be inspired by Nancy Fraser's understanding of social recognition, but You-tien Hsing and Ching Kwan Lee do not go into detail on this and do not take up Fraser's explicit reference to Western societies. Laurence Roulleau-Berger has stated that demands for recognition arise from situations of social, economic, and ethnic inequality and elaborates on the emergence of intermediate spaces in Chinese society producing "grammars of recognition and contempt." Laurence Roulleau-Berger, "Multiple Modernities, Inequalities and Intermediate Spaces," in Laurence Roulleau-Berger and Li Peilin (eds), European and Chinese Sociologies: A New Dialogue, Leiden, Brill 2012, p.88.

17. Axel Honneth, "Redistribution as Recognition: A Response to Nancy Fraser," Redistribution or Recognition? A Political-Philosophical Exchange, op. cit., p. 157. 
velopment project's progression since 2007 and its planning and regulatory framework.

\section{Old town neighbourhood - flair of Xiguan culture}

Like other Chinese cities, Guangzhou has undergone comprehensive restructuring. The associated intercity competition and entrepreneurial municipal strategies have placed a priority on urban planning. ${ }^{(18)}$ In this shift toward the market, urban land reform has become the major fulcrum for reshaping the spatial structure of the city. The introduction of market value has accelerated the conversion of industrial and residential land to commercial use. In addition, decentralisation of economic decision-making has strengthened the role of municipalities in organising urban development. New economic agents have appeared, and government regulations and market forces are coalescing. ${ }^{(19)}$ Along with entrepreneurial discourses, Guangzhou is presenting itself as an economic and metropolitan centre and a "world-class city" (shijie wenhua mingcheng 世界文化名城), and has recently also been stressing its local cultural heritage as an asset. (20)

In the heart of the old town of Guangzhou, centrally located between a busy pedestrian zone and a popular park and with excellent public transportation, lies a former Cantonese opera neighbourhood and choice piece of property in the eyes of entrepreneurial local governments, investors, and real estate agents. Its southern border is formed by Xiguanlu Road, (21) which gives the area and redevelopment project its name. Considered representative of local Xiguan culture (xiguan wenhua 西关文化), the arcades (qilou 骑楼) in the tall buildings lining Xiguanlu Road offer protection against sun and rain, and are an inviting place to stroll with countless small businesses, shops, and restaurants. The neighbourhood is also home to the historical "Golden Voice" cinema, of which however only the facade still exists today. Xiguan (western suburb) was the name used in the eighteenth and nineteenth centuries for what is currently part of the old town of Guangzhou (or Canton as it was then called in the West). It was settled by foreign traders and vendors who were not allowed to reside within the walled city itself. (22) When the city became the only open port for foreigners in China in 1759, Xiguan rapidly blossomed into a centre for trade.

In contrast to the lively activity on the surrounding streets, Xiguanlu tends to be a quiet and peaceful neighbourhood - at least before turning into a demolition theme park. Paved with traditional slabs of granite (mashi 麻石), its alleys are too narrow for vehicular traffic but are an appealing place to chat with neighbours and view historical buildings from different eras. Distinctive tripartite doors in the Xiguan buildings (xiguan dawu 西关大屋) are a common sight, consisting of a half-height, curved and often carved double structure (jiaomen 脚门) on the outside, then a full-length barred gate (tanglong 趟栊) in the middle providing security but also letting in air and light, and then a solid, heavy wooden door (damumen 大木门) on the inside.

With residents from different social backgrounds, numerous nearby shops and facilities, a relatively high population density, and close neighbourly contact, the Xiguanlu redevelopment area reflects in certain ways the ideal of New Urbanism. ${ }^{(23)}$ Noteworthy here is that metropolitan redevelopment projects worldwide spend great effort countering societal segmentation in order to achieve what was already present in Xiguanlu. Thus it might seem ironic that a neighbourhood like Xiguanlu, which embodied numerous integrative factors and possessed a special historical flair, was suddenly struck by the wrecking ball. Instead of using the neighbourhood's strengths to

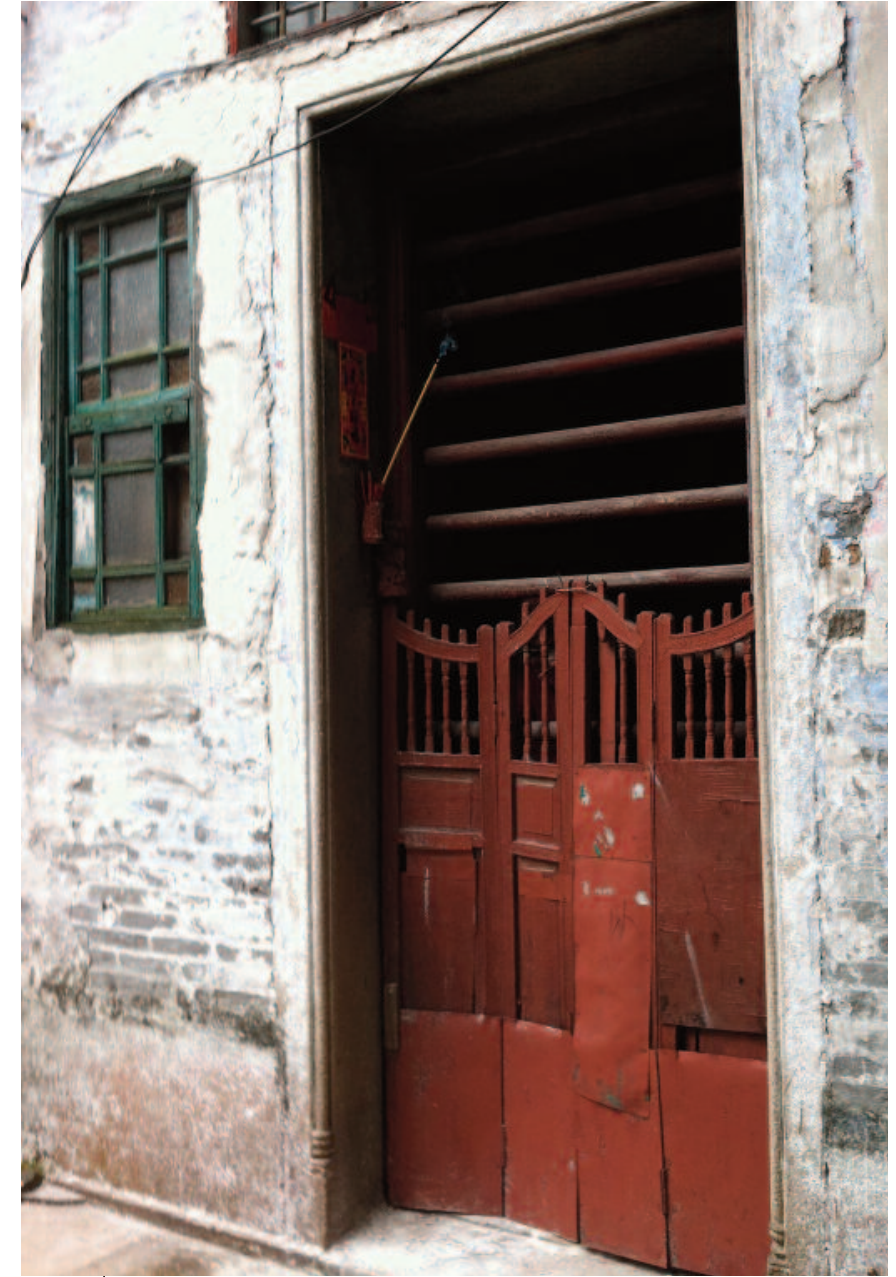

Photo 1 - Traditional tripartite door of a Xiguan building (c) Bettina Gransow

counter the threat of polarisation in urban society, the redevelopment project itself now threatens to further this polarisation.

\section{Redevelopment as social intervention - "Demolition before planning"}

The Xiguanlu redevelopment project was first mentioned in late 2006 as one of five planned urban renewal projects in Guangzhou. Its total building floor space is 20.71 hectares. Some 2.45 hectares were to be preserved on account of their unique characteristics. ${ }^{(24)}$ Some 14.14 hectares were sub-

18. Fulong Wu, Jiang $\mathrm{Xu}$, and Anthony Gar-On Yeh, Urban Development in Post-Reform China: State, Market and Space, London, Routledge, 2007, p. 180

19. Ibid., pp. 233, 236

20. Developing Guangzhou into a culturally rich world-class city was the topic of the 2010 Guangzhou Summit Forum.

21. The actual name of the road, which is also used for the neighbourhood and the redevelopment project, has been altered to "Xiguanlu" to preserve the privacy of the residents. "Lu" is Chinese for road.

22. Michael Tsin, Nation, Governance and Modernity in China: Canton 1900-1927, Stanford, Stanford University Press, 1999, p. 20

23. New Urbanism is a movement that arose in the USA in the late twentieth century to counter urban sprawl. It seeks to integrate residential, working, and shopping spaces based on the model of historical city centres.

24. Exhibition brochure January 2012, 11 pages (in Chinese); Hyun Bang Shin, "Elite Vision Before People: State Entrepreneurialism and the Limits of Participation," in Uwe Altrock and Sonia Schoon (eds), Maturing Megacities: The Pearl River Delta in Progressive Transformation, Dordrecht, Springer, 2014, p. 270. 


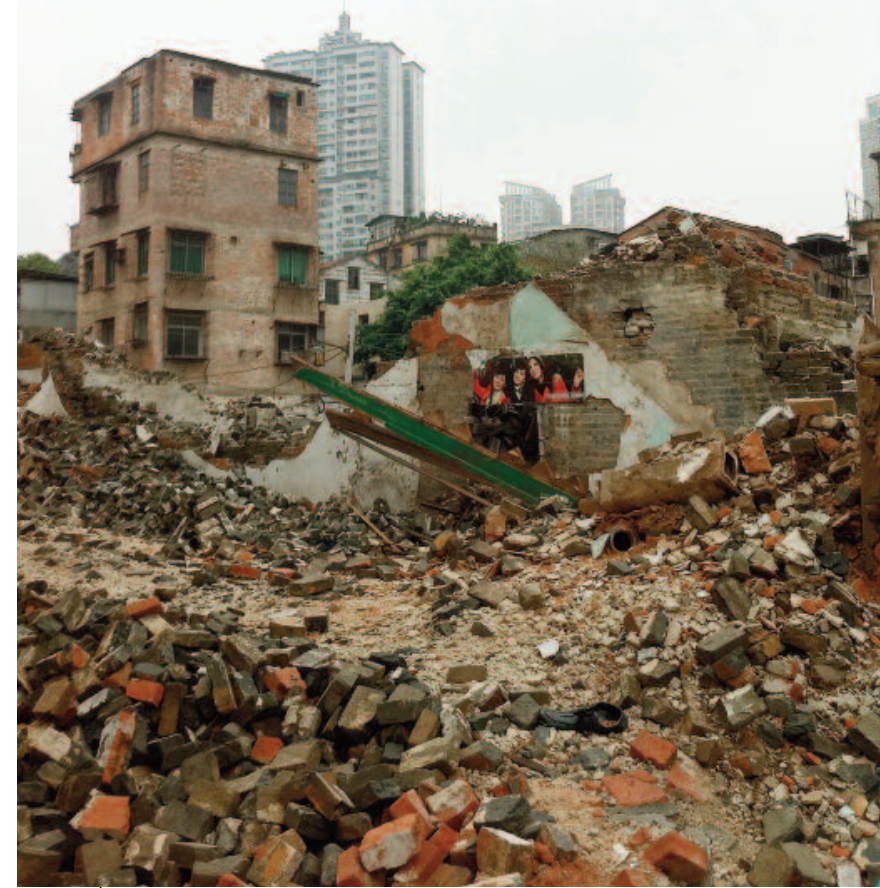

Photo 2 - Demolition in the "Xiguanlu" redevelopment project area $\odot$ Bettina Gransow

ject to demolition requiring permanent displacement of 1,950 households, both those in public rental units managed by the municipality and those owned privately. Besides the residents, key stakeholders in the project were the municipal and district governments with their respective planning bureaus and district branch offices, the resettlement office, the municipal land resource and housing administrative bureau, and the land use and development centre responsible for cash compensation and relocation costs. (25)

Redevelopment of Xiguanlu was initially approached under the motto of "all buildings should be torn down" and "all residents can return to their homes." Whereas the second part of the motto was received positively by residents, the first part was sharply criticised for claiming that historical buildings should not be protected and that even the famous Qilou buildings on Xiguanlu Road should be replaced by new high rises. In 2007, the Guangzhou municipal government backed down, the plan was revised, and the Qilou buildings were supposed to be preserved - albeit only the architectural monuments (wenwu 文物). With an international call for tenders the city then sought a comprehensive draft plan for the area. In April of 2008, the Guangzhou Municipal Planning Office approved a plan for protecting and utilising historical architecture in the project area that was designated a "dilapidated housing redevelopment district." One month later, homeowners from Xiguanlu sent a letter to the National People's Congress stating that the planned demolition work would violate the Property Law (Wuquanfa 物 权法) of $2007^{(26)}$ and that the plan should be recalled or changed.

Despite this unresolved situation, demolition began in November 2008. At this point 954 households, or fewer than half of those affected, had signed a compensation agreement. (27) In December 2009, the local government presented a plan for protecting and developing what was now called a "historical and cultural district" (lishi wenhua jiequ 历史文化街区), emphasising culture, leisure, and tourism. The change expressed by this plan becomes more understandable when one considers that Guangdong Province and thus the city of Guangzhou were basing their planning efforts on the "Three Olds" (sanjiu 三旧) policy. (28) This document from the province gave the green light for large-scale urban redevelopment, yet also contained guidelines for greater public participation.

In August 2010, the mayor of Guangzhou visited the project area and stated that it should become a model for improving lives, preserving culture, and restoring the old town. In March 2011, the district government decided to preserve 120 historical buildings, including former residences of Cantonese opera singers. In June 2011, the planning committee of the city of Guangzhou passed a new redevelopment plan for Xiguanlu, (29) which was finally published in January 2012. It stated that only an additional 50 households should be resettled, and emphasised a new motto that "all buildings of historical and cultural value should be preserved" and "original residents can retain their home ownership." To be on the safe side, however, it stressed to the press that "it will not be possible for all the residents to return." (30) This was nearly the exact opposite of the plan's original motto from 2007. Residents increasingly came to the conclusion that the plans for establishing a Xiguan Old Town tourist area were in large part commercially motivated. Their remaining hopes of returning to the neighbourhood were dashed with the publication of this plan.

As a critical conclusion, it remains a fact that the project was not conceived to pursue overarching, well-considered, and comprehensible aims of old town redevelopment. Instead, the city thereby secured valuable land as a resource for commercial activities. As such, the project planning served less as a guide for rational and ordered implementation than as an instrument for removing a good number of residents from the area as quickly as possible in order to begin tearing down the buildings. This created facts on the ground that made it less attractive for the remaining residents to stick it out amid the rubble, dirt, and ruins while dealing with noise, dust, decreasing safety, and numerous other problems.

Of relevance here is that the "Regulations for Expropriation and Compensation for Houses on State-Owned Land" (Guoyou tudi shang fangwu zhengshou yu buchang tiaoli 国有土地上房屋征收与补偿条例) of $2011^{(31)}$ put a new legal basis into effect that replaced the regulation on demolition and compulsory resettlement in effect since 2001. These new Expropriation Regulations address citizen's concerns much more than before, for example by basing compensation on the market value of new flats. A draft of these

25. For a detailed analysis of the various actors involved in urban redevelopment from a planning perspective see (for Shanghai) Zhang Kai, "Who is Relocating Whom in the Renovation of Shanghai's Old City?", China Perspectives, No. 2013/1, pp. 29-39.

26. The Chinese Property Law defines all forms of property in the PR China and the associated rights: state, collective, and private. It states that the creation, transfer, and destruction of immovable property rights require registration.

27. Hyun Bang Shin, "Elite Vision Before People," art. cit., p. 274; Exhibition brochure, op. cit., p. 8.

28. Guangdong sheng renmin zhengfu guanyu tuijin "san jiu" gaizao cujin jieyue jiyue yongdi de ruogan yijian (Some Suggestions of the People's Government of Guangdong Province on Advancing "Three Olds" Redevelopment and Promoting Land Conservation and Intensive Land Use) (2009). The "Three Olds" policy (document No. 78) refers to old villages-in-the-city, industrial areas, and residential districts and their redevelopment. Press conference on Guangzhou's "Three-Olds Redevelopment" program, 18 August 2010, www.gz.gov.cn/business/htmlfiles/gzgoven/s7467/20 1101/719458.html (accessed on 5 December 2013); see also Sonia Schoon, "Three Olds: Experimental Urban Restructuring with Chinese Characteristics, Guangzhou and Shenzhen in Comparison," in Uwe Altrock and Sonia Schoon (eds), Maturing Megacities, op. cit., pp. 105-121.

29. Wei Kai, "Jumin quanbu huiqian bu keneng" (It will not be possible for all the residents to return), Nanfang dushibao, 21 September 2011.

30. Liu Xue, "[Xiguan] lu chaiqian zai yanqi" (Demolition of Xiguanlu extended again), Nanfang dushibao, 25 June 2011, p. A06.

31. Promulgated by the State Council. 
2011 Expropriation Regulations had already been under discussion for several years previously, although repeatedly delayed due to resistance by local governments for whom the purchase of land had become a major source of income. (32) The 2011 Expropriation Regulations assign a dominant role to the government in expropriation and compensation, and prohibit agencies such as real estate builders, developers, and demolition companies from engaging in these activities. ${ }^{(33)}$ If citizens do not accept expropriation decisions, they have the right to apply for administrative reconsideration. These new regulations also improve the standards and evaluation methods for compensation as well as for settling disputes over unregistered buildings. Disputes are to be settled before expropriation just as compensation is to be provided before relocation. Moreover, the new regulations also address low-income issues for the first time, expressing legislators' concern for the situation of socially disadvantaged groups. All in all, these new regulations represent a considerable advance in protecting the rights of persons facing expropriation and resettlement. Crucially, they lay out the conditions under which expropriation may be undertaken in the public interest and also require greater transparency. The 2011 Expropriation Regulations are a clear example of how new laws and directives came out after the start of the Xiguanlu project, which - if consistently applied - would have improved the situation for residents.

For a project like this it would have been necessary to assess the potential social impact and risks before the actual work began. Although there is no Social Assessment Law in China corresponding to the Environmental Assessment Law of 2003, there do exist guidelines and recommendations which could have been used to develop social action plans for those affected - especially for vulnerable groups - with the aim of enabling appropriate participation in the project's benefits. ${ }^{(34)}$ Despite their relative advancement over earlier regulations, the Expropriation Regulations of 2011 are hardly suitable for this purpose. Although they require a public hearing before expropriation and also call for a "social stability risk evaluation report" (Shehui wending fengxian pinggu baogao 社会稳定风险评估报告), this report focuses on the risks that protesting citizens might pose to smooth operations and thus cause longer and more expensive projects as opposed to the social risks and impact on those affected. The approach would thus appear to be misguided, and in danger of achieving precisely the opposite results. In fact, it creates incentives to raise the spectre of social unrest in order to make use of funding to maintain social stability.

\section{Conflicts of recognition and citizen activism}

The conflicts faced by residents in the Xiguanlu neighbourhood have changed in character, expanded, and become more varied since the start of the demolition and relocation process. What started as largely a reaction to resettlement and compensation measures has deepened into debate over the local historical significance of the neighbourhood and into an array of ideas about the future of both the neighbourhood and its residents. Over the course of this process, different actors have become involved such as experts, the media, and civil society, and also new and public means have been used such as websites, lectures, workshops, films, music videos, and exhibitions to provide information about Xiguanlu and thus to encourage discussion of redevelopment and gentrification-related problems in old town neighbourhoods.

Protests by the residents of Xiguanlu and their contestation of space can be analysed as conflicts of recognition in at least four different dimensions, including: (1) an economic dimension focusing on the project's criteria for setting compensation levels, combined with demands for distributive justice; (2) a social dimension directed toward the recognition of neighbours' "lived space" (Henri Lefebvre); (3) a cultural dimension with residents demanding preservation and restoration of local Xiguan culture; and (4) a political dimension revolving around disregard for the problems that redevelopment has created for residents and their feelings of belonging, views, and knowledge of the place. A key component here is the demand to be accepted as partners in the negotiating process by the local authorities and government with regard to the future of their own lives and that of their neighbourhood.

\section{Economic recognition: Protesting and negotiating compensation standards}

The idea of having to leave a familiar neighbourhood and relocate to an outlying district was a challenge for many residents of the Xiguanlu neighbourhood. At the start of the project in 2007, some 1,950 households were to be resettled, of which 723 were renting from the city and 1,277 were under private terms (both tenants and owners). Whereas the tenants in municipally-owned spaces were obliged to move out without much ado as of 2008 and 2009, negotiations with tenants and owners under private agreement were much more complicated. At issue were the conditions, standards, and levels of compensation, but also and especially the unclear ownership titles. In July 2009, some 634 households in privately-owned buildings had not signed compensation agreements, including 136 households from weak socioeconomic backgrounds. By March 2010 this number had declined slightly to 563 . The effects of the project in terms of entitlement to compensation for the loss of their living space were very different for the various groups of tenants and owners. ${ }^{(35)}$

"Tenants in publically owned flats" (gongfang zuhu 公房租户), many of whom were themselves various types of civil servants, could either accept the government's arrangements and move into flats located mainly on the outskirts of Guangzhou or find other housing themselves and receive a subsidy of 1,600 yuan per square metre. In any case they had to move out, and tenants of publically owned flats were the first to leave Xiguanlu. They later complained about the poor quality of their new flats, high management fees, additional costs for public transportation, an absence of markets, and broken familial networks. Particular difficulties were encountered by extended families who had had more space in the Xiguan buildings and could no longer accommodate all their members. Nevertheless, the recognition pattern of paternalist care by the local government versus subordination of the residents seems to have been generally operative in

32. Matthew Erie, "Property Rights, Legal Consciousness and the New Media in China:The Hard Case of the 'Toughest Nail-house in History'," China Information, Vol. 26, No. 1, 2012, p. 51.

33. Yan Jun and Chen Haiting, "Understanding the Regulations on Expropriation and Compensation of Housing on State-Owned Land," China Bulletin, November 2011, www.kingandwood.com (accessed on 28 December 2013). Local governments were also prohibited from commissioning demolition companies on their own. This was designed to reflect the basic legal principle that administrative regulations are distinct from implementation and may not be used to determine the latter.

34. See Touzi xiangmu kexingxing yanjiu zhinan (Guideline for Investment Project Feasibility Study). Approved by the State Planning and Development Commission of China, Beijing 2002; Bettina Gransow and Susanna Price (eds, revised English version), Social Assessment Manual for Investment Projects in China - Turning Risks Into Opportunities, Compiled by China International Engineering Consulting Corporation, Beijing, China Planning Press, 2007.

35. The following analysis of entitlement groups is based on "Jumin shou yingxiang qingkuang zongjie" (Summary of the situation of [project] affected residents), 5 pages (2010). 
the case of tenants in publically owned flats moving to the outskirts of the city.

Other complaints over compensation had to do with living space that for historical reasons had been administered only provisionally by the government (daiguan fangzi 代管房子) and lacked the legal conditions for compensation. Daiguan fangzi refers to residences whose lawful owners cannot be determined and so are administered by the municipal housing department. Compensation conditions are the same as for tenants in publically owned flats. Some households, however, view themselves as owners instead of tenants and are consequently dissatisfied. A second problem has to do with "co-ownership" of flats that cannot be divided. Dissatisfaction is especially high here, because these individuals are denied recognition as owners and view the fact of little or no compensation as unjust.

"Tenants in privately-owned flats" (sifang zuhu 私房租户) are the most negatively affected. Rental contracts are the sole source of eligibility for compensation. This especially affects long-time tenants and migrants. Longtime tenants who had for example taken over flats from relatives a long time ago but whose landlords could no longer be reached have difficulty demonstrating their eligibility for compensation. Migrants as a specific group of tenants in privately-owned flats who are permanently registered at another location also lack a claim to compensation, even if they have lived for a long period of time with their families in the project area.

"Private homeowners" (sifang yezhu 私房业主) can choose between cash compensation and exchanging their flat for another piece of real estate. Two groups of private homeowners have to be distinguished: those of relatively small flats and those of larger flats or houses. Low-income families with only one flat smaller than $40 \mathrm{~m}^{2}$ were eligible for compensation based on a minimum size of $40 \mathrm{~m}^{2}$. (36) Because the standard unit was set at 9,000 yuan $/ \mathrm{m}^{2}$, owners could receive compensation of 360,000 yuan. This could well enable them to purchase a flat of $70-80 \mathrm{~m}^{2}$ in a suburb for somewhat more than 200,000 yuan and then have money left over Similar to tenants in publicly owned flats who had no means of resisting relocation, the 400 households that owned only small flats had no way to get around the "irresistible offer" in practical terms either. A generous compensation offer meant that this group could be easily "bought out" of the area. Here the dominant recognition pattern is a market-like exchange; but combined with the paternalist care/submission pattern this group would have had practically no means of refusing financially attractive offers.

Many of the remaining homeowners initially imagined that they would return to the area following redevelopment and "buy back in" (yuandi huiqian 原地回迁). But it quickly became apparent that the monetary compensation on offer was not sufficient to do so. In a protest letter to the Standing Committee of the local People's Congress (Guangzhou shi renmin daibiao dahui changwu weiyuanhui 广州市人民代表大会常务委员会) dated 23 November 2009, a group of residents complained that "the cash compensation is too low. Although it was said that the standard figure should be $9,000 \mathrm{yuan} / \mathrm{m}^{2}$ (reflecting the estimated market price $+20 \%$ old town allowance + buyer subsidy of 1,200 yuan $/ \mathrm{m}^{2}+$ bonus of 500 yuan $/ \mathrm{m}^{2}$ for signing the contract on time), in fact, however, often only 8,000 or even 7,000 yuan $/ \mathrm{m}^{2}$ was paid. This is not enough even for 'second-hand' flats, which are going for 10,000 yuan $/ \mathrm{m}^{2}$, let alone first-occupancy flats with prices of $15,000-17,000$ yuan $/ \mathrm{m}^{2}$." (37) The buy-back idea was therefore unfeasible for arithmetical reasons alone. This was one of the main reasons why the compensation for owner-occupied flats was deemed unjust (bu gongzheng 不公正).
Criticism was also directed at the measurement of living space. Because the individual storeys of the old Xiguan buildings are very high, the surface area actually in use was two to three times the floor area itself, but only the floor area was used for calculations. Owners of larger flats and houses can be identified primarily with a market-like recognition pattern. If they feel the pattern is violated, they do not hesitate to fight for a fair price.

"Shop owners and leaseholders" (ziyou shangpu he shangpu zuhu 自有商 铺和商铺租户). Private owners of flats who have set up shops (zhugaishang 住改商) - a situation first made possible by reform policy - cannot receive compensation via the "shop for shop" method, nor can they return to their shops following the completion of the renewal project. This affects most of the shops in the Xiguanlu arcades, and the owners are very unhappy as a consequence. In general the owners of small shops in the area complain that business has worsened since redevelopment was announced and that the situation is declining all the more as their neighbours move out.

The entitlement to receive compensation and the type of compensation itself, including its standards and level, are matters of huge importance to the residents. The list of different types of entitlement reflects a social hierarchy, the lowest rung of which consists of those with no recourse to compensation whatsoever. Based on their position within the hierarchy, individual households face different opportunities and risks that could mean financial gain or conversely a worsening of their situation.

\section{Social recognition: Decrying the rupture of family and residential networks}

The Xiguanlu neighbourhood is a mesh of individual, family, organisational, community, and business networks. Individual families as well as social groups emphasised their dependence on social networks to greater or lesser degrees. Older residents who have spent decades in the neighbourhood and residents who have small shops are especially unwilling to leave. The social hierarchy that arises from the recognition or non-recognition of economic loss and its compensation or lack thereof as well as from the differing degrees of bargaining power appears grosso modo to stand in inverse relation to the degree of dependence that these "compensation" groups have on social networks. On the lowest rung of the hierarchy are the rural-to-urban migrants who live in Xiguanlu with their families or relatives and who work or have small shops nearby. Because they have to rely on informal arrangements in many areas of their lives, the economic loss and the higher cost of living that they anticipate from having to leave Xiguanlu without compensation are exacerbated by the destruction of their local networks. Here there is a clear lack of arrangement for those who have no recognisable legal right or claim to the place where they are living. Rural migrants, for example, should receive an appropriate form of resettlement assistance if they have lived in the project area prior to a cut-off date established by the project authority. ${ }^{(38)}$ The Expropriation Regulations of 2011 should be supplemented by a clause that addresses the rights of migrants-in-the-city and

36. Jiucheng lianpian gaizao xiangmu chaiqian gongzuo xuanchuan shouce (Brochure on demolition work in a contiguous old town redevelopment project), July 2009, p. 2.

37. Letter dated 23 November 2009, author's translation from Chinese. For $m^{2}$ price levels for firsthand and second-hand property, see Ryanne Flock, Werner Breitung, and Li Lixun, "Commodity Housing and the Socio-Spatial Structure in Guangzhou - A Study Based on Estate-Level Residential Property Prices," China Perspectives, No. 2013/2, p. 45.

38. See for example World Bank Involuntary Resettlement Policy OP/BP 4.12, in World Bank (ed), Involuntary Resettlement Sourcebook. Planning and Implementation in Development Projects, Washington 2004, Appendix 1, pp. 375-376. 
protects them from the consequences of redevelopment projects and the loss of their livelihoods. Because the paternalist recognition pattern does not cover migrants-in-the-city and because civil society is not strong enough to effectively advocate for their needs, migrants are driven further to the margins of urban society.

Resettlement also unleashes stress in many families due to multiple simultaneous decisions that affect key parts of their members' lives. This can include splitting up households as a result of displacement. It can also affect marriages, jobs, schooling, care for children, elderly, or ill family members, and other areas as well. (39) Moreover, the range of community services on offer drops dramatically when a redevelopment project progresses and organisational structures and networks dissolve or change accordingly. The residents' committee (juweihui 居委会), which used to be open to neighbourhood concerns, is no longer viewed as a helpful partner but rather as an organisation that unilaterally advances the redevelopment project and advises residents to move away. There is also said to be no support from the street office (jiedaoban 街道办), which by law should exercise a guiding function over the now disappointing residents' committee. At the same time, new organisations have appeared, such as the demolition office (chaiqian bangongshi 拆迁办公室), with which the residents tend to communicate only when unavoidable.

The rupture of family and neighbourhood networks contributes to frustration, especially among the poor and elderly but also among homeowners. As trust declined in both existing and newly arisen grass-roots organisations, residents began to close ranks, work more closely together, and address their concerns to higher levels. While problems caused by the redevelopment project are left to society, political control and suppression of civil society activities and organisations are producing a social vacuum and undermining social cohesion. As such, the recognition pattern of pluralisation and participation can take effect here only in very limited form.

Faced with a growing supremacy of powers favouring demolition and spurred by increasing mistrust, the residents and particularly the homeowners have become ever more active and united over time. Their activities also create opportunities and entry points for support on the part of experts, the media, and student groups. Support - and thus also recognition - has been provided by committed young people who became interested in the planning processes, local history, residents, and their social conditions and dynamics. By compiling background material, holding interviews, making films and music videos, holding academic workshops with international comparisons of redevelopment projects, inviting experts, and arranging exhibitions both large and small, they have done much to document and respond to the redevelopment project from a number of perspectives. ${ }^{(40)}$

\section{Cultural recognition: Protecting the place and its history}

Fuelled initially by largely practical concerns about the preservation of their homes, but later also with a broader understanding of local identity, residents turned the changing trials of redevelopment "planning" into a process of reflecting on local culture and cultural authenticity. Considerations included preservation, relations between cultural and social history, public interest in redevelopment in Xiguanlu, and their own responsibility and ownership. In the process they realised their desire not only to stay but also to apply their own ideas on how to recreate their neighbourhood.
The Guangzhou planning authorities viewed Shanghai's Xintiandi (上海新 天地) project as the model for redevelopment in Xiguanlu. ${ }^{(41)}$ Xintiandi represents the introduction of modern consumerism and lifestyles in restored Shikumen (石库门) houses, ${ }^{(42)}$ which were reinvented as popular shopping and leisure sites. Whereas the buildings were carefully preserved (at least from outside), low and middle-income residents had to leave the area to make way for local elites, expatriates, and tourists. ${ }^{(43)}$

The residents of Xiguanlu tend to be critical of this model. "We can't learn anything from Shanghai's Xintiandi; we want our real Xiguan back" (bu neng xue Shanghai Xintiandi, yao hui women zhenzheng de Xiguan 不能学上海 新天地, 要回我们真正的西关). (44) Cultural authenticity cannot be achieved if historical buildings remain only as empty "crab shells" (xieke 蟹壳), they say. The "Golden Voice" cinema in Xiguanlu Road, built in 1934, is cited as a negative example; despite vehement warnings and protests, it was reduced to a facade, and its unique acoustics are now irretrievably lost. The law on intangible cultural heritage (Zhonghua renmin gongheguo wenwu baohufa 中华人民共和国文物保护法, 2007) and the "Three Olds" policy (2009) fuelled their discussions. Groups met over early-morning tea to discuss not only the preservation of historical buildings and their architectural aesthetics but also their practical use and related questions of a living transfer of culture. In January 2012, the Guangzhou urban planning office published a "Guangzhou Municipal Plan to Preserve Cultural-Historical Cities" (Guangzhou shi lishi wenhua mingcheng baohu guihua 广州市历史文化名 城保护规划) and called for public response within 30 days. Shortly before the deadline, 78 neighbours from Xiguanlu proposed that in addition to the 22 existing "cultural-historical neighbourhoods" in Guangzhou, the Xiguanlu neighbourhood should be recognised as the $23^{\text {rd }}$ on this list, emphasising the former residences of Cantonese Opera stars, a guild hall for opera ensembles, and a school of martial arts. ${ }^{(45)}$ Their proposal was accepted. It represented a success for the neighbourhood's activists - but also a success for the planners and local government, who despite all the preceding planning mishaps could now bask in having fulfilled in exemplary manner the latest guidelines on preserving historical buildings and ensuring public participation.

\section{Political recognition: Demanding public participation}

The first collective action by residents came in November 2009, after demolition of a building caused a neighbouring building to lean dangerously. Fearing that their safety was no longer ensured, 50 neighbours wrote a letter to the Guangzhou municipal government, and then to the petition office of the city's People's Congress demanding that construction work not be started until residents were relocated (xian anzhi hou chaiqian 先安着后拆

39. Personal notes from group interview with project affected residents, 16 June 2010.

40. See for example, http://site.douban.com/lovecanton/ (accessed on 2 April 2014).

41. Xintiandi is a part of the larger Taipingqiao redevelopment project in Shanghai. Fulong Wu, liang Xu, Anthony Gar-On Yeh, Urban Development in Post-Reform China, op. cit., pp. 249-251.

42. Shikumen or stone gate houses, are two to three-storey buildings in Shanghai blending features of East and West. The origin of these buildings can be traced to the Taiping revolution in 1860, when local merchants invested in housing to accommodate refugees from Jiangsu and Zhejiang in the foreign settlements of Shanghai.

43. Fulong Wu, Jiang $\mathrm{Xu}$, and Anthony Gar-On Yeh, Urban Development in Post-Reform China, op. cit., p. 251.

44. Zhendui [Xiguan] lu dikuai gengxin gaizao guihua de yijianshu (Comment on the renewed redevelopment plan on Xiguanlu area), Appendix 1: Records of group interview on 2 May 2010, p. 48.

45. Mo Guanting, "Jiefang xu [Xiguan] lu ru 'lishi wenhua jiequ"' (Neighbourhood calls for including Xiguanlu as cultural-historical neighbourhood'), Guangzhou ribao, 4 February 2012. 
迁), and that higher compensation be paid to allow for the purchase of comparable living space. ${ }^{(46)}$

In January 2010 a "new style" district plan was presented, which divided the project area into six operational areas, all of which were commercially oriented. Residents were outraged that their neighbourhood would be further ruined without a precise plan or legal basis. They wrote another protest letter with 220 signatures containing proposals for improvement such as monitoring the project for its social effects, holding a hearing to air the views of experts, scholars, and the public at large, postponing demolition until publication of an official plan, following the rules for preserving historical neighbourhoods, and proceeding with redevelopment in accordance with the principles of law and the protection of ownership. ${ }^{(47)}$ Whilst these various petitions did receive written replies, the replies continued to consist largely of conveying the positions of the planning and administrative offices.

Despite their numerous activities, residents emphasise that these were apolitical in nature. "Indeed, why did we do all these things? We didn't just want to air our grievances (wuli qunao 无理取闹) ... but we'd like to live our lives, drink tea, and chat with the neighbours, maintain the Xiguan style of life. We're not against urban development! It's just that it has to be based on laws and regulations that take account of people's lives, like finding a new place first and then tearing things down." (48) Talks and interviews frequently produced comments like "the government really doesn't listen to us" (shishi shang, zhengfu bu kenting womende 事实上, 政府不肯听我们 的), or "our voice is not loud enough" (womende shengyin xianzai tai xiao 我们的声音现在太小). ${ }^{(49)}$

The inadequacy of the planning process was due in part to insufficient information, transparency, and involvement by citizens. It was not until the Expropriation Regulations of 2011 that the legal foundations were laid for public hearings to be held before compensation plans are finalised. More extensive forms of participation would have been conceivable, however, such as stakeholder workshops, or participation in action plans by marginalised groups. Many legal procedural issues could also be considerably improved. In general, the procedural requirements for citizen participation are vague, public hearings can be manipulated, and there is insufficient representation or other means to achieve clearly defined results. ${ }^{(50)}$

The homeowners have been especially active in making use of participatory opportunities, such that some researchers have compared them to interest or lobby groups. ${ }^{(51)}$ If they succeed in remaining in the neighbourhood with their homes and putting their idea of "soft" urban renewal into practice, they will be among the small number of residents who can count themselves winners.

The asymmetrical property and power structures that were present beforehand but were concealed by the integrative functions of neighbourhood networks and facilities have broken through under the pressure of the redevelopment intervention and are clearly evident in individual groups' different levels of bargaining power. Social inequality has been turned inside out, so to speak, and made manifest spatially as social segregation.

\section{Conclusion}

Social differences and unequal property relations existing in the neighbourhood before the project began were less evident and were also mitigated by the effects of family and community networks. The assignment of individual households to different entitlement groups for compensation, which could be like winning a lottery ticket or incurring a steep loss, exerts considerable leverage with respect to social hierarchies and polarisation and is also reflected spatially in relocation. This means that most residents have had to leave the popular neighbourhood. Of the fewer than $25 \%$ still living in the project area in 2013 , the majority are too poor and/or old to move, have unclear ownership and compensation conditions, or are among the few homeowners who have succeeded in remaining.

Analysing protests and debates about the old town redevelopment project in the form of residents' conflicts of recognition vis-à-vis local government and its administrative offices reveals the dynamic character of these conflicts, which assume economic, social, cultural, and political dimensions and are played out in the course of disputes over compensation, the loss of family and neighbourhood networks, the preservation of historical buildings, and the lack of opportunities to participate in planning and implementing the project. This analysis shows how the conflicts can intensify, dissolve, or become more ordered with changes in legal or economic framework conditions; in any event such changes in the rules of the game place the points of dispute on a new basis, which in turn can be recognised (or disputed) by the parties in conflict. This applies especially to new laws and regulations, in particular to those regarding property rights (2007), preserving cultural heritage (2007), and house expropriation and compensation, including the conditions for participation (2011) that all went into effect after project work had begun, and thus unleashed dispute over their applicability to the project already underway. Rapidly rising prices for real estate led to earlier compensation offers no longer being viewed as appropriate. This dynamic also appeared in disputes over the area's cultural and historical significance. As the residents - in the face of loss - became aware of not only their neighbourhood's architectural appeal and historical flair but also the close connection between the local architecture, including its cultural and historical traditions and their own Xiguan lifestyle in the quiet alleyways surrounded by lively commercial roads in the centre of Guangzhou, they started to work for a soft form of redevelopment in order to save what they still could of the semi-demolished area.

Of those involved in collective action against the form taken by the redevelopment project, owners of larger flats or houses are represented more strongly than people of lower social classes, who have generally been hit by the project in far more existential ways. In other words, those who have suffered the greatest consequences of the redevelopment project are generally not those who are most active in opposing its negative effects. Although improved integration of rural-to-urban migrants is a declared aim of Chinese urbanisation policy, this new social group that has arisen in the course of social transformation in the country - along with the new group of urban middle-class homeowners - has been completely ignored in the Xiguanlu project. The paternalist recognition pattern has shown itself to be particulate, and does not cover migrants-in-the-city, who have to find new living space and possibly also new jobs on their own. Although they are especially negatively affected, they were not involved in any protest actions in Xiguanlu. One might speculate whether this is due primarily to their low

46. Letter dated 23 November 2009

47. Letter dated 29 March 2010.

48. Speech by a resident during a Xiguanlu exhibition opening, 23 December 2011.

49. Zhendui [Xiguan] lu dikuai gengxin gaizao guihua de yijianshu, op. cit., p.63.

50. See Jiang Yihong, "Altering the Rules: Chinese Homeowners' Participation in Policy Making," art. cit., p. 132.

51. Ibid., pp. 132-137; see also the papers in this issue by Amy Zhang and Aurore Merle on homeowner activities. 
number in the neighbourhood and their insufficient bargaining power, or to a self-image founded less on their living conditions in the city and more on their status as workers (given the otherwise numerous strikes and collective actions by migrant workers), or quite simply to the hukou system, which has led to migrants as non-hukou holders not making any claims on urban spaces. Regarding citizen activism within this case study, no direct correlation can be drawn between the degree of affectedness by the redevelopment project and the degree of participation in collective activism on the part of individual social groups. This hypothesis should be tested in the course of further empirical studies.

Finally, it has to be mentioned that residents' demands for recognition and participation in shaping the outcomes of the redevelopment project clearly showed the limits of the "demolition before planning" approach taken by the project management, which was not based on clear procedural regula- tions but instead consisted of reaching agreements on disputed matters oneby-one with the individual households. Whilst this type of bargaining can often achieve rapid solutions, it also carries the risk of undesirable side effects that can be very costly. By contrast, greater participation before and during such projects in the form of timely information, counselling, and involvement by both residents and the public at large would make solutions considerably more sustainable and probably also less expensive. In many cases, greater investment in socially sustainable project planning and implementation can surely prevent subsequent expenses "to maintain social stability."

I Bettina Gransow is Associate Professor of Chinese Studies at the East Asian Institute at Freie Universität Berlin.

Freie Universität Berlin, East Asian Institute, Ehrenbergstr. 26-28, 14195 Berlin, Germany (bgransow@zedat.fu-berlin.de). 